quality hay to keep the eight hippos alive, and Michaela and I offered to help by starting a small fund for the hippos of Lake Baringo. The Wild Life Society headed the subscription list with a gift of $£ 50$ and although we received contributions from as far afield as the United States, most of the money came from conservationists we knew in Kenya. Within a few weeks we had enough to guarantee the hippo's food for as long as the drought lasted.

Soon we saw a remarkable difference in the habits of the hippos. They began to develop confidence in people. Normally, hippos spend most of the day well off shore and land only at night, but these soon started lying in the shallow water during the day, not more than twenty or thirty yards from the men loading the fish into David's freezing plant. In the evening they would come out of the water, start eating long before dark, and stay out until daybreak. One evening I actually saw David pat one of the hippos on the back as it waddled past on the way to the house for the day's ration. All this was very satisfactory except for one thing that began to worry David as the drought went on.

He knew the Africans well who lived around the lake and he understood how the drought was hitting them. They were beginning to go hungry too, and he knew that the longer the drought lasted the more of a temptation these nearly tamed hippos would become. He knew just how serious this danger was when he saw one of the hippos with a spear sticking out of its back. It was not a bad wound and David was able to get the spear out. But the day came when David had to leave home for a week. When he returned he found that the big old bull had been speared to death in his absence. A few weeks later, another followed. Then a female was killed and her baby caught in the mud and choked to death. Within a matter of weeks, the last of the eight hippos we thought we had saved had been killed, and the animals exterminated from one more African lake. Ultimately several of the Africans responsible for the killings were arrested and imprisoned for a while, but the sentence struck me as being almost as pointless as it was unfair.

\title{
Bird Sanctuary in India
}

THE Wildlife Reserve, created out of the Maharajah of Bharatpur's former hunting park, $90 \mathrm{~km}$. from Delhi, is described by an FPS member, the Rev. Dr. A. C. Bouquet, who visited it in February, as " one of the best water-bird sanctuaries in the world. We saw a hundred Siberian cranes, about 200 white pelicans from central Asia, several hundred painted storks and their nests, adjutants and other varieties of stork, black, purple, and white ibis, spoonbills, stilts, avocets, egrets, at least five varieties of heron, a magnificent flight of a dozen sarus cranes, demoiselle cranes, hundreds of duck of many species, and many small waders. ... The bird life of the jungle is also profuse, with large flocks of the commoner Indian birds such as green pigeons, rose-ringed parrakeets, and bee-eaters, and less common species." The reserve is controlled by the Forestry Department in conjunction with the Bombay Natural History Society, with a warden in charge, and the royal hunting-lodge has been converted into a guest house.

$A_{\text {straightforward, factual and attractively produced children's book with }}^{P E S \text { and }}$
a remarkable amount of information and no trace of condescension in its
thirty pages, about half of which are taken up with Barry Driscoll's spendidly
lifelike drawings. The finger tapping of the aye-aye, why monkeys make
faces, and the intelligence of chimpanzees are subjects to fascinate any child. 